\title{
Vulvar Cancer TNM Finding v7
}

National Cancer Institute

\section{Source}

National Cancer Institute. Vulvar Cancer TNM Finding v7. NCI Thesaurus. Code C89417.

A finding about one or more characteristics of vulvar cancer, following the rules of the

TNM AJCC v7 classification system. Vulvar cancer is a surgically staged malignancy. (from AJCC 7th Ed.) 